\title{
What Factors Determine the Purchase Intention of Haläl Products by Porto-Muslim Consumers?
}

\author{
Nasir Ahmad ${ }^{1 *}$, Susana C. Silva ${ }^{2}$, Paulo Duarte ${ }^{3}$, Fábio S. Sandes ${ }^{4}$ \\ ${ }^{1,2}$ Católica Porto Business School, Universidade Católica Portuguesa \& CEGE, Lisbon, Portugal \\ ${ }^{3}$ NECE-Research Centre in Business Sciences, Universidade da Beira Interior, Covilhá, Portugal \\ ${ }^{4}$ Universidade Lusófona - CICANT, Lisbon, Portugal
}

\section{Keywords \\ Purchase Intention \\ Halāl Products \\ Halāl Market \\ Muslim Community \\ Muslim Consumer}

Received: 22 February 2021

Accepted: 15 May 2021

\begin{abstract}
Purpose: This article aims to identify and discuss the drawbacks faced by Muslim consumers to consume halāl products when living in cities where they are a minority group. For this study, we considered the Muslim population living in Porto, Portugal. This study also aims to understand the attributes of the Muslim consumer that drive the purchase intention of halāl products.
\end{abstract}

Methodology: A survey was carried out to understand the problems and the opportunities of the Muslim Community living in Porto and analyze the drivers that motivate them to buy haläl Products. The sample consisted of 173 valid responses. The research applied the theory of planned behavior as a theoretical framework.

Findings: The results of the multiple regression analysis indicate that the subjective norm has a positive and significant influence on the intention to purchase halāl food among Muslims living in Porto. Furthermore, there is evidence of a lack of adequate supply of haläl-certified products in Porto.

Significance: There are few studies about the consumption habits of Muslim consumers in cities where they are a minority group, where access to halāl products is limited. This study aims to contribute to this discussion. Limitations: As the objective of this research was to identify and discuss the drawbacks faced by consumers in a minority group, the sample size in this study is small. Therefore, the generalization of the findings is limited. Our results showcase the relevance of subjective norm on purchase intention, even in conditions where the supply of halāl foods is limited. Practical Implication: Our results indicate that the supply of halāl products is limited in Porto, Portugal, and Muslim consumers' demand for such products is still unmet, allowing companies to invest in targeting this market.

KAUJIE Classification: $\mathrm{H} 32, \mathrm{H} 33$

JEL Classification: L08, L26

\footnotetext{
${ }^{*}$ Corresponding author: Nasir Ahmad

†Email: nasirsahel@yahoo.com; ORCID: https://orcid.org/0000-0003-3681-3970
} 


\section{INTRODUCTION}

For hundreds of years, religion has played an essential role in the formation of beliefs and morals of individuals, affecting the evaluation that consumers make of advertisements and products, and in many cases determining purchasing decisions (Farah, 2020). Refusing specific types of food is not a recent phenomenon; on the contrary, it derives from ancient civilizations. Many were determined in the past due to unknown motives and are still present and have even gained more significant support from religious sanctions (Bonne \& Verbeke, 2008).

For Muslims, all food products need to go through a process called halāl to be seen as safe, clean, and healthy. Therefore food needs to be prepared with hala $\bar{l}$ lingredients exclusively, following the principles of Sharī'ah (Ahmed et al., 2019). For instance, under Islamic rule, animals must be slaughtered with a sharp knife that accelerates the blood flow, resulting in a more humane death.

Furthermore, Islam demands obedience to God's will and legislation, which means that all of the everyday behavior of Muslims are demonstrations of worship. Moreover, a person is a "Good Muslim" when they conform and follow God's rules (Noor, Farah, \& Aflah, 2014). This is how one of his rules involves the consumption of only haläl Products (HP). Indeed, when we translate halāl from the Qur'ānic, allowed or legal are the closest to the meaning of this word and are related to the eating habits specified in the Qur'ān book. This book states that all foods are halāl, except those considered as harām, illegal or forbidden (Shah $\&$ Mohamed, 2011). In the face of Islam, the voluntary consumption of any harām food is considered an offense, so the consumption of halāl food is mandatory for every Muslim unless he is in a situation where his life is at risk ${ }^{i}$.

Because of the strict dietary rules demanded by religion, the number of people who follow them is significant, even by consumers that do not live in Islamic countries (Bonne \& Verbeke, 2008). For example, it is estimated that three-quarters of Muslims living in the U.S. follow their dietary laws, which means that most Muslims still eat halāl even after they have migrated. Another study by Bonne and Vermeir (2007) showed that $84 \%$ of Muslims exclusively eat halāl meat in France. Therefore, it would be interesting to closely examine how the haläl market in Porto works with the Muslim community.

Moreover, just a few years ago, the Muslim population surpasses the two billion mark in the world. The population is spread in 112 different countries, most of them in the Organization of the Islamic Conference (1.4 billion) and Asia (805 million). Some are also in Africa (300 million), the Middle East (210 million), and Europe (18 million) ${ }^{2}$ (Shah \& Mohamed, 2011). Therefore, Islam is the religion that grows the fastest globally, as the Muslim community is large and representative. Consequently, the haläl food market offers exceptional opportunities, and it is a lucrative market globally, so it should not be ignored or dismissed (Shah \& Mohamed, 2011). However, this anecdotal evidence suggests that the gap in discussing how Muslim consumers' behavior in foreign countries- especially where they are a small part of the population-needs further research and discussion.

\footnotetext{
${ }^{1}$ https://Halal.pt/valor-do-Halal/

${ }^{2}$ www.mida.gov.my
} 
Today, educated young Muslim consumers are expressing their demand for halāl-friendly merchandise, and they are responsible for the increase in the global relevance of Muslim communities (Abdul-Talib \& Abd-Razak, 2013). Besides, researchers agree on the lack of awareness of consumer attitudes and levels of awareness regarding haläl certification (Ahmed et al., 2019) as this certification and its awareness may be smaller in cities where the Muslim community is a minority. Thus, we have decided to investigate the drivers of haläl consumption from Muslim consumers living in Porto, a place where they are a minority group, and the offer of haläl-certified products is limited.

This article aims first to understand the attributes that drive the purchase intention (PI) of Muslim consumers towards Haläl Products (HP) in Porto city. To do that, we have analyzed and used previous research on this topic. And then to identify the main drawbacks faced by the Muslim community living in Porto regarding obtaining HP, which could be the basis for considering this as a market opportunity to develop a haläl business in Porto. Considering these objectives, we have proceeded to formulate the following question: What factors determine the Purchase Intention of haläl Products by Muslim consumers living in Porto?

To answer it, we need to discuss the importance and drivers that motivate this community to purchase specifically haläl products (HP) and then analyze the current situation of the Porto market concerning this product, identifying the main problems and opportunities for improvement.

The study will help professionals, researchers, and policymakers in their respective analyses about the demand for HP and understand the needs of this rapidly emerging and even more adept market. At a macro level, this work also collaborates to the understanding of the supply and demand of HP in the city of Porto, the second-largest city of Portugal, which has even a smaller Muslim population than the capital, Lisbon (Kettani, 2010). According to Portugal's statistics, in the Metropolitan Area of Lisbon (European Commision, 2020) Resides $69 \%$ of Muslims living in the country.

Porto was conveniently selected because the Muslim community is a minority, and no previous studies investigated halāl consumption in the city. Moreover, there are still very few studies about the haläl market in countries with small Muslim communities, such as Portugal. Therefore, the scope of this article is to understand how this Muslim community copes with the apparent lack of certified HP and what role this absence would play in the possible interest in opening a halāl business.

\section{LITERATURE REVIEW}

\section{Muslim Community and Food Needs}

For a long time, religion has been seen as one of the main reasons for food evasion, taboos, and specific controls concerning meat (Bonne \& Verbeke, 2008). The literature suggests that it is attributed to the religious conviction that it is considered vitally important to follow and respect consumption patterns among Muslims, even in non-Muslim countries (Salman \& Siddiqui, 2014). Muslims must follow what is designated in Islamic law. The Qur'ān contains the primary sources of the Sharī'ah, which govern the Muslim community (Noor et al., 2014). 
Furthermore, it is considered a religious obligation that all Muslims must eat only hala $\bar{l}$ food, therefore by Sharī'ah (Islamic) principles, and will be Toyyib, manifesting goodness and wholesomeness (World halāl Forum, 2009). In addition, Islam strongly disapproves of the consumption of harām foods and emphasizes the prohibition of products of dubious origin (Abu et al., 2018).

Concerning food recipes in Islam, Muslims must commit to specific eating behavior that aims to strengthen their health, complying with the five pillars of Islam: Alms (zakāh), Fasting (sawm), Profession of Faith (shahädah), Prayer (salät), and Pilgrimage (Hajj). These dietary laws or prescriptions determine which foods are haläl (permitted) for Muslims (Bonne $\&$ Verbeke, 2008).

Finally, Muslims are characterized as being super-connected in a network of relationships that guides and influences their social behavior. Thus, the consumption of "non-halāl" food can isolate a consumer from the Muslim community, possibly affecting their relationships with family and friends, as some members may treat them as a social "outcast" because they do not meet the standards of Islam (Salman \& Siddiqui, 2014). Shafique et al. (2019) studied Muslim consumers' behavior in style shopping inventory and found that Muslim consumers tend to be less impulsive and buy in a less recreational way than non-Muslim consumers.

\section{Haläl Products and Certification}

Haläl means legal or permitted. Islamic Shari' 'ah law mentions that any food allowed to be eaten halāl (Ahmed et al., 2019). Therefore, nowadays, the concept of halāl surpasses the food market, is also related to cosmetics, personal care, pharmaceuticals, and other products. Linguistically, halāl is a comprehensive concept that incentivizes Muslim consumers to buy more healthy products in their lives' physical and spiritual areas (Abdul-Talib \& Abd-Razak, 2013). Moreover, the opposite of halāl is harām, which is defined as something forbidden or illegal. Therefore, one of the central doctrines of Islam is that Muslims not only buy and use HP but also refrain from using anything that is considered harām.

Not only are halāl foods famous for strictly adhering to Islamic law, but they are also considered a good option for a healthy diet because of the way they are processed and prepared. However, not all foods can be considered haläl until backed by their respective "halāl food certification" or "halāl food clergy." These certifications are easy to find due to the likelihood of adulteration in foods of this type (Salman \& Siddiqui, 2014). Giyahi and Khashei Varnamkhasti's (2019) studies with Iranian consumers showed that an effective branding strategy for HP is necessary.

To inform if a product is halāl or not, producers use halāl certification. It is a certification that states that these products follow all the rules, processes, and specifications set out in their traditions (Shah \& Mohamed, 2011). That is why today, Muslims living in countries outside the Islamic community are making their social and political presence felt by demanding haläl-certified food products (Bonne \& Verbeke, 2008).

In Portugal, the leading certifier institute is called "halāl Institute of Portugal," and this is an institute that analysis the certification of the product of halāl for consumption and it will carry a regular audit of the product, assuring that the correctness of HP is guaranteed. The 
inspectors of this institute are trained with ISO standards and haläl standards and well trained in quality management, aiming to eliminate the Portuguese consumer doubts. Consequently, it guarantees 100 percent confidence of the auditors for the certification. Moreover, the product certified by this institute is posted on their website. These products (except meat) exist not only in halāl shops but also in Portuguese supermarkets. The halāl Institute of Portugal obtained accreditation from the authorities of the Ministry of Environment and Water of the United Arab Emirates in 2014².

The Muslim community has expressed deep concern about the authenticity of the HP they consume due to excessive artificiality and dubious halāl labeling in the food industry. To address the need for clarifying this concern, uniform verification by an independent certification body is necessary. Therefore, the haläl Institute of Portugal aims to serve the Muslim community in this objective and support all industries that seek to cover new markets globally.

\section{Haläl Market}

The food industry has neglected the Muslim market. To understand the potential of the halāl market, it is essential to mention that Muslims are close to 2 billion consumers worldwide, and Islam is the fastest-growing religion in the world (Abdul-Talib \& Abd-Razak, 2013). This also emphasizes that the market for haläl foods in non-Muslim countries is substantial and that the haläl market in non-Muslim countries offers great opportunities for companies (Noor et al., 2014).

For the following years, the global Muslim population is expected to increase from 23 percent to about 30 percent of the world population by 2030 (Grand View Research, 2018). That same year, the global haläl market might reach $\$ 10$ trillion (Ali \& Sherwani, 2017). Recent data shows that the value of the halāl Market was U\$ 4.4 trillion in 2016, and it is provisioned to reach U\$ 7.4 trillion by $2025^{4}$.

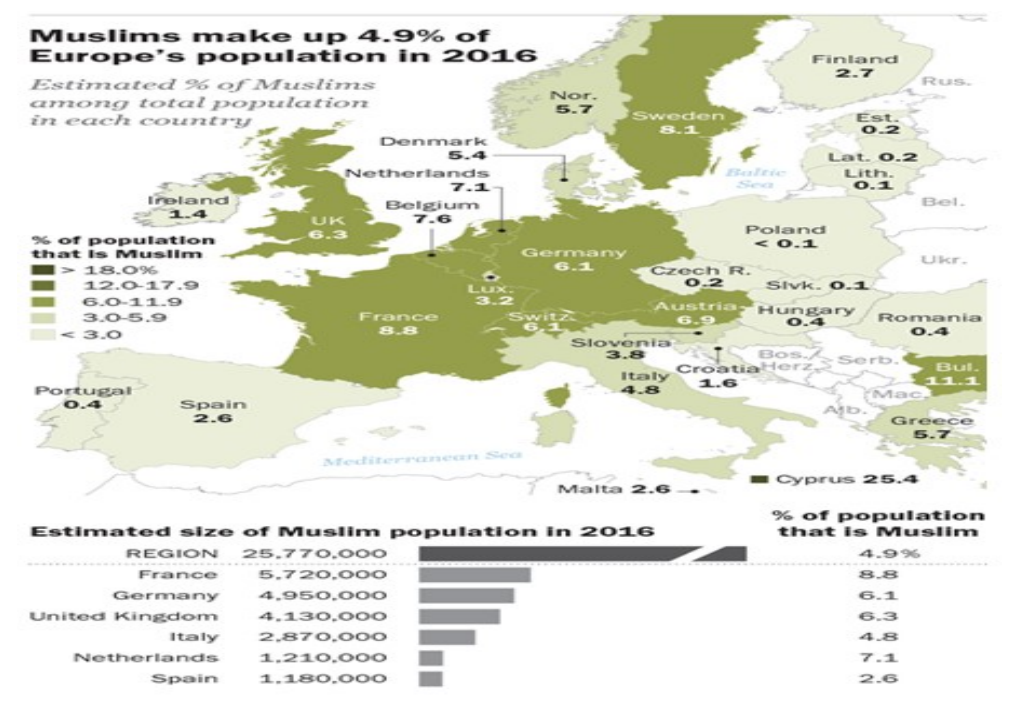

FIGURE 1. Muslim Population in Europe

\footnotetext{
${ }^{3}$ https://Halal.pt/en/certificacao/

${ }^{4}$ (Grand View Research, 2018)
} 
In recent years, Europe has experienced an unprecedented influx of immigrants predominantly from Muslim countries, with France and Germany ranking first and second as the countries with the largest Muslim community in the region. However, in Portugal, Muslims number only 65,000 , representing only $0.4 \%$ of the country's total population. The data was taken from the Pew Research Centre report on the Muslim population in Europe.

From a commercial perspective, the Islamic haläl food demand is growing at the fastest pace globally, mainly due to two motives: religious enthusiasm and the belief that halāl food is healthier, tastier, and cleaner. Secondly, because of the process of assimilation where the halāl food is being accepted within the population. It is increasingly common for foreign foods in some European countries to be assimilated, adopted, as changes in taste are encouraged by reverse colonization and tourism (Shah \& Mohamed, 2011).

\section{Theory of Planned Behaviour TPB}

Several studies on consumption support TPB (Ajzen, 1991; Taylor \& Todd, 1995), including specific research on food choices (Aditami, 2016; Bonne et al., 2007; Bonne \& Verbeke, 2008). These studies have found that food-related behavior is also related to self-identification as a predictive variable (Bonne et al., 2007). Besides, Bonne et al. (2007) study conducted in France about attitudes towards purchasing halāl meat showed the considerable importance of perceived control, social norms, and attitude on the intent to consume haläl meat. Furthermore, Noor et al. (2014) show that TPB is valid to predict the intention of Muslim consumers to purchase HP, and for consumers with both high and low Islamic religiousness, their PI is mostly determined by subjective norms.

Halāl food consumption, subjective norm, and perceived behavior control positively influence Muslims' halāl food buying intention (Shah \& Mohamed, 2011). Consequently, Ajzen (1991) developed one of the most widely supported and empirically comprehensive frameworks for purchasing intent. This research was tested using the TPB framework.

In addition, the study of Awan et al. (2015), among minority Muslims living in France, used the TPB model as a framework to be applied in the context of food, religion, and migration. This study was insightful as it added the dimensions of self-identity, habits, and food acculturation in an adaptation of the TPB model (Awan et al., 2015).

\section{Purchase Intention}

Religion is a relevant part of decision-making, as it influences a person to behave legally, ethically, and according to the principles of their religion (Ahmad et al., 2015). With motivation and self-identity, religiosity to adhere to Sharī'ah guidance determines PI for HP (Farah, 2020). However, health, degree of acculturation, and concern with animal welfare are also determinants for consuming these products (Bonne \& Verbeke, 2008).

Religiosity can be defined as the degree individuals hold and practices beliefs they might have in specific religious ideals and values (Delener, 1994). Practitioners can say that someone who is highly religious integrates his religion into much of his life as Muslims do (Noor et al., 2014). Cultural awareness can significantly impact the way people see and practice their religion, especially in Islam, where culture and customs can be a factor in the practice 
of Islamic Sharī'ah (Awan et al., 2015). Ajzen (2008) explained that PI is a forecast about the level of customer awareness and attitude and can affect the buying decision of future customers.

\section{Subjective Norm}

According to the principles of the TPB, subjective norms are social pressures perceived by individuals that finally lead them to perform or not perform a specific behavior (Noor et al., 2014). This driver is handy when it comes to religious communities where several rules must be complied with, as is the case with Muslims. Based on previous research and results, Shah and Mohamed (2011) proposed that if halāl food shopping is socially desirable among Muslims, consumers are more likely to adhere to this norm and buy haläl's food (Shah \& Mohamed, 2011). Therefore, we consider the subjective norm as the perceived social pressure that influences consumers' decisions to buy HP. We suggest four hypotheses: H1: Purchase Intention and subjective norm to buy haläl Products are expected to have a positive relationship.

\section{Self-Identity}

Self-identity as a "Muslim" is related to the pressure that an individual faces to act in a manner considered acceptable in a Muslim society (Salman \& Siddiqui, 2014). In collectivist societies where there is an influence of a reference group, behavioral traits are attributed to society's spiritual/religious origins (Lindridge, 2002; Lindridge \& Dibb, 2003). A clear example of such collective societies is the Muslim community and their well-known customs such as fasting, charity work, pilgrimages, etc. Such customs are part of their identity and are what characterize and distinguish them from the rest. Then, we propose the hypothesis: H2: There is a positive relationship between self-identity and purchase intention to halāl Products.

\section{Perceived Behavioral Control}

The third driver is the control of perceived behavior, which refers to the perception of how difficult it is to carry out a particular behavior (Noor et al., 2014). Control of perceived behavior is how a person participates in the behavior (Ajzen,1991). The individual's beliefs determine such control about the internal factors and the relevance of situational circumstances to ease the recognition of the behavior.

Commonly, when someone thinks they have more resources available, such as time, money, and skills, their perception of control is high. Therefore, their behavioral intentions increase (Shah \& Mohamed, 2011). Therefore, the more control an individual has over purchasing halāl food. It is more likely that they would do it. We considered the control of perceived behavior is the ability to buy HP. Moreover, we propose the following hypothesis: H3. The relation between perceived behavior control and the purchase intention of halāl Products is positive. 


\section{Attitude towards Haläl Food}

Finally, In the TPB, the attitude towards the behavior is the first component, which is explained as the degree of favorable or unfavorable reaction of a person (evaluation and assessment) to realize a specific behavior (Ajzen, 1991). Broadly, the more in line the attitude towards behavior, and the greater the perception of control over the behavior, the stronger is the person's intention to perform this behavior (Alam \& Mohamed, 2011).

Religion can influence consumers' attitudes and behavior, including eating habits and food buying decisions (Mullen et al., 2000; Delener, 1994; Pettinger et al., 2004). Following Alam and Sayuti (2011), someone whose beliefs result from a specific positive behavior will positively affect that compartment. Conversely, someone whose beliefs result from negative behavior will negatively affect carrying out that behavior.

Behavior is determined by behavioral beliefs that link the behavior to various outcomes. Therefore, attitude is essential to predict and describe human behavior (Ajzen, 1991). Thus, we proposed that: H4: Attitude and Intent to purchase Halāl Products are expected to have a positive relationship.

Consequently, with these variables (subjective norm, self-identity, perceived behavior control, and attitude towards Haläl food), we have assembled the following framework: the object of our study. We expect to verify if there is a positive and direct relationship between self-identity, attitude, subjective norm, and perceived control of behavior as independent variables to apply to the specific study on the PI of HP (dependent variable) in the Muslim community of Porto.

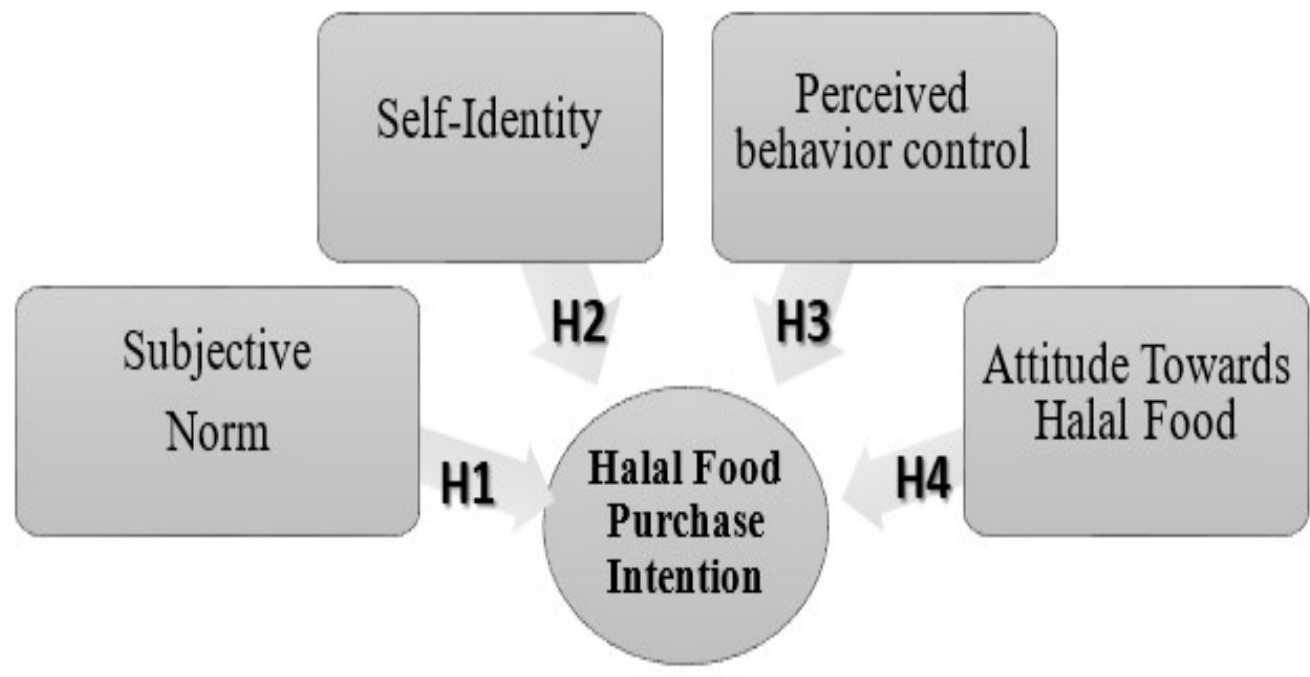

FIGURE 2. Framework 


\section{METHODOLOGY}

The quantitative research and the exploratory case study methodology were chosen to understand and discuss the factors the determine the PI of HP, aimimg to help answer the question, "What factors determine the Purchase Intention of Haläl Products by Porto-Muslim consumers?". Ajzen's TPB (1985) is the framework used in this study. This is a wellfounded theoretical framework on purchasing intent with strong empirical evidence and has been used in previous studies on haläl food purchases (Ali et al., 2018; Bonne et al., 2007; Bonne \& Verbeke, 2008; Shah et al., 2019; Shah \& Mohamed, 2011).

\section{Data Collection}

To obtain research data, questionnaires in electronic format have been distributed to adults 21 years of age or older who are Muslims and reside in Porto and may or may not be concerned about halāl food Purchase Intention. Moreover, using the questionnaire in a case study is viable (Saunders et al., 2000). Besides, this allows us to describe a group of people or objects and understand their conditions (Park \& Park, 2016). The use of an online questionnaire offers relevant gains, such as low cost, rapid response time, and the potential of reaching many cases (Malhotra et al., 2010). In total, 173 valid surveys were obtained from two sources. The first source was an online form, where we obtained only 77 valid responses. As it was not sufficient, we decided to print the forms and survey members from Muslim associations living in Porto. The result of the face-to-face data collection was 96 valid responses.

\section{Measures}

All the elements destined to measure the variables of the present study were instruments previously validated related to the object of study. Subjective norm was measured with scales obtained in the research of (Ajzen, 1991; Venkatesh \& Davis, 2000). In the application of our survey, the necessary modifications were made so that the focus was on the purchase of HP. Similarly, the perceived behavior control and attitude used measures indicated in the research previously carried out by Taylor and Todd (1995). In self-identity, the statements were adapted from the studies of (Awan et al., 2015; Delener, 1994; Salman \& Siddiqui, 2014). Moreover, in the case of intention to purchase, we adapted the statements formulated in the studies (Kamalul et al., 2019; Phan \& Mai, 2016; Wee et al., 2014). All items in the measures used in this study used a 5-points Likert scale. Items and references for the measures can be found in the Appendix of this article.

\section{Results and Analysis}

All the questions used to run the regression model used a Likert scale (5 points). Furthermore, we used regression analysis to analyze the survey results. In total, 173 valid surveys were obtained from two sources. The first one was collected through the online form. We achieved just 77 surveys; however, because the number was not representative, we decided to print the same forms and survey the Muslim associations living in Porto. The result of the face-to-face data collection was 96 surveys. Both bases were processed in Excel before being transferred to the SPSS, where all the analyses were carried out. 
TABLE 1

Correlations

\begin{tabular}{|c|c|c|c|c|c|c|}
\hline Variables & M & "Subjective_Norm_SBN & "Purchase_Intention_PI & Perceived_Behaviour_PB & "Attitude_ATT & "Self_Identity_SI \\
\hline Subjective Norm (SBN) & 4.325 & 1 & & & & \\
\hline Purchase_Intention (PI) & 4.151 & $.528 * *$ & 1 & & & \\
\hline Perceived_Behaviour_PB & 4.374 & $.538 * *$ & $.285^{* *}$ & 1 & & \\
\hline Attitude_ATT & 4.409 & $.691 * *$ & $.392 * *$ & $.471 * *$ & 1 & \\
\hline Self_Identity_SI & 4.35 & $.731 * *$ & $.367 * *$ & $.582 * *$ & $.710 * *$ & 1 \\
\hline
\end{tabular}

**. Correlation is significant at the 0.01 level (2-tailed).

\section{Reliability}

The internal reliability was tested by Cronbach's alpha (Shah \& Mohamed, 2011), and we used as a standard the suggested minimum alpha of 0.6 (Shah \& Mohamed, 2011). Table 1 below displays all Cronbach's alpha coefficients were equal to above the 0.7 thresholds. The constructs were considered reliable.

TABLE 2

Cronbach's Alpha of Constructs used in this Study)

\begin{tabular}{llllllll}
\hline \hline \multicolumn{2}{c}{ Subjective Norm } & \multicolumn{2}{c}{ Perceived Behavior Control } & \multicolumn{2}{c}{ Attitude Towards Haläl } & \multicolumn{2}{c}{ Self-Identity } \\
\hline Cronbach's Alpha & N of Items & Cronbach's Alpha & N of Items & Cronbach's Alpha & N of Items & Cronbach's Alpha & N of Items \\
\hline .792 & 4 & .875 & 4 & .700 & 4 & .729 & 4 \\
\hline \hline
\end{tabular}

\section{Multicollinearity and Normality of Data}

Two methods determined the presence of multicollinearity among the independent variables in this study. These methodologies involved calculating a tolerance test and variance inflation factor (VIF) (Ali et al., 2018).

Regression results show that only the variable "Subjective Norm" has a statistically significant tolerance level $(p<0.001)$. Variables "Perceived Behavior" $(\mathrm{p}=0.885)$, "Attitude Towards Haläl Food" ( $p=0.412)$, and "Self-Identity" ( $p=0.457)$ did not present a statistically significant tolerance level. It is important to stress that all VIF values are well below 3 (varying from 1.58 to 2.83). Thus, when assessing independent variables, we could not find levels that indicate multicollinearity. The main results of the regression analysis are presented in Table 3 below:

TABLE 3

Regression Analysis

\begin{tabular}{llllllll}
\hline \hline Variables & \multicolumn{2}{l}{ Unstandardized Coefficients } & Standardized Coefficients & \multicolumn{4}{c}{ Collinearity Statistics } \\
\hline & $\beta$ & Std. Error & $\beta$ & t & Sig. & Tolerance & VIF \\
\hline (Constant) & 2.674 & .262 & & 10.196 & .000 & & \\
Subjective_Norm_SBN & .329 & .065 & .525 & 5.043 & .000 & .393 & 2.544 \\
Perceived_Behaviour_PB & .010 & .070 & .012 & .145 & .885 & .633 & 1.580 \\
Attitude_ATT & .056 & .068 & .082 & .822 & .412 & .432 & 2.313 \\
Self_Identity_SI & -.055 & .073 & -.082 & -.746 & .457 & .353 & 2.833 \\
\hline \hline
\end{tabular}

Dependent Variable: Purchase_Intention_PI

\section{Hypotheses Testing}

Multiple regression prediction models tested the proposed hypothesis, similar to the analysis 
used in previous studies (e.g., Dutta \& Mandal, 2018). Haläl food PI is the dependent variable. Therefore, the results provided support for $\mathrm{H} 1$, that is, a statistically significant positive relationship between Subjective Norms $(\beta=0.329$ and $p<0.000)$ on haläl food purchase intention (Dutta \& Mandal, 2018). We found no significant relationship between Haläl Food, Self-Identity, Perceived Behaviour, and the dependent variable, leading to the rejection of $\mathrm{H} 2, \mathrm{H} 3$, and $\mathrm{H} 4$.

TABLE 4

Model Summary

\begin{tabular}{llllll}
\hline \hline Model & R & R Square & Adjusted R Square & Std. Error & Durbin-Watson \\
\hline 1 & $.532 \mathrm{a}$ & .283 & .266 & .39513 & 1.629 \\
\hline \hline
\end{tabular}

TABLE 5

ANOVA

\begin{tabular}{lllllll}
\hline \hline Model & & Sum of Squares & df & Mean Square & F & Sig. \\
\hline 1 & Regression & 10.350 & 4 & 2.587 & 16.573 & .000 \\
& Residual & 26.230 & .168 & .156 & & \\
& Total & 36.579 & 172 & & & \\
\hline \hline
\end{tabular}

\section{Porto's Muslim Business Case}

To better understand the current situation of the hala $l$ market in Porto, we asked additional questions in the survey, which allow us to identify the needs of this type of consumer. The results of these questions helped us to confirm our speculations about the state of the HP supply in Porto. In general, the following images show an insufficient supply of HP in Porto, a certain dissatisfaction among consumers, and a need for more haläl distributors in Porto. $86 \%$ of the respondents confirm that they frequently and even always consume HP as set out in the rules of their religion. With this result, we can confirm that most Muslims living in Porto try to follow the rules of their religion. We have found that $35 \%$ of the total surveyed spend more than 150 euros per month on the purchase of HP. $61 \%$ of the respondents declare that they know only one shop in Porto. According to our studies, there are just three exclusive $h a l a \bar{l} l$ shops in Porto. These results indicate that there is a lack of supply for these kinds of products.

Regarding the categories that Muslims usually buy, $92.5 \%$ of the respondents go to halāl shops to buy Food and Beverages exclusively. Other categories are not so demanding even though the rules of Islam state that consumption must be of HP. More than 56\% disagree that they can find and buy all the products they need. Therefore, we can infer a lack of supply to meet all consumer needs for HP.

Our results also indicate that $49 \%$ of the respondents do not agree that haläl shops are well located and are difficult to find in Porto, $47.4 \%$ are dissatisfied with the current availability of 
halāl stores, $76.3 \%$ of respondents also confirmed that there are not enough halāl stores in the city, and $90.3 \%$ wish more stores were selling HP in the region. Altogether, these results show potentially an excellent opportunity for new businesses to engage in the marketing of HP. If they are well located and have a good variety of products, it could be a key lever for their success.

\section{DISCUSSION}

Our research focused on identifying which factors determine the intent to purchase HP by Muslims living in Porto. We ran a quantitative analysis and applied a survey aimed at our target audience. We expected almost the same results as those obtained by the studies consulted since we used the same variables. These results can be contrasted with previous studies: Shah and Mohamed (2011) found in their research in Malaysia that all relationships in the TPB model were positive, with high values of the significance level. However, comparing the findings of Shah and Mohamed (2011), we can say that our results differ partially from theirs because we only have one variable that explains more strongly than the others, the same PI. However, the relationship tested in this research suggests that not all relationships are significantly applying the same model in the Muslim community living in Porto.

However, the study by Noor et al. (2014), which also used the theoretical framework of the TPB, concluded that for Muslims with both high and low religiousness, subjective norms are the most influential in HP PI, which is consistent with our results, reinforcing our findings (Shah \& Mohamed, 2011). Moreover, our results in the case of the subjective norm are similar to those found in the studies of Ali et al. (2018) and Bonne and Verbeke (2008). With the results of these studies and our own, we could say that buying haläl food is considered a socially requested behavior among Muslims. Its result or action has much to do with the opinion of others. Moreover, a Muslim consumer is likely to purchase halāl food due to the social pressure they feel from their community. Finally, our results can also be explained because the subjective norm becomes more potent when dealing with more collectivist societies than individualists as Muslims are (Bonne, 2007).

Behavioral control is the degree to which a person feels capable of performing the behavior (Ajzen, 1991). Typically, when someone feels they have more resources and more opportunities, their perceptions of control and intent are high (Shah \& Mohamed, 2011). However, according to the responses to our study, we could justify that our perceived behavioral control did not have the desired level of significance because respondents reported that they did not have specific facilities for purchasing HP, which could be explained by the lack of adequate shops with certified products.

We can therefore conclude that the Muslim community living in Porto tries to abide by the subjective norm following the social pressure about the consumption of HP, the reasons for which, as explained by other researchers, are based on the fact that they are a collective community and that they follow the rules set out in the Koran and try to respect its principles. Furthermore, it can be observed that Muslims, despite living in countries that are not in line with their customs and where they are a minority, nevertheless try to follow their subjective rules established previously in their religion. Considering the research results and consistent 
with other studies, we see that the demand for HP is expanding worldwide, and Portugal is no exception. This increase is due to a larger population of Muslims but mainly because their communities maintain and fulfill their traditions, such as searching for and consuming HP. Furthermore, as Salman and Siddiqui (2014) stated, there is currently a surge in demand for services and products that consider consumers' spiritual and worldly needs. Therefore, this strong demand also indicates a challenging, subjective norm among buyers. Because of this, we appreciate that hala $l$ certification is fundamental in countries where there are Muslim communities, no matter how minor they are.

\section{Conclusion}

We aimed to discuss which factors determine the PI of HP by Muslim consumers in a city where the Muslim population is small. We decided to conduct our study in Porto, Portugal, a city that fits into this description. Our framework was the TPB model. We now list our findings' theoretical and managerial implications, comparing our results with the results we found in previous studies. Later we present and discuss the limitations of our study and propose new pathways for future studies regarding Muslim consumers' behavior in foreign countries, which still needs to be further discussed in literature by marketing and business researchers.

\section{Theoretical Implications}

Theoretically, it can be shown that a generalization of TPB in the context of halāl foods must be made very carefully. Since the consumption of halāl food is strongly related to its spiritual principles and religious elements, purchasing behavior is more prone to uncertainty. Previously, some studies found positive relationships between the elements of TPB and purchase intent. However, in our study, the results show significant differences between TPB and PI elements. It is likely that haläl purchasing behavior changes according to the situation; for example, in the Porto Muslim community, we must consider that they are not representative in numbers. Furthermore, the community is composed of different nationalities, that although they all follow the principles of the Koran, not all do so with the same enthusiasm. It is also essential to consider the situation of the Muslims living in Porto, the majority of whom are immigrants with low income or refugees and therefore do not all have the same ability to afford the price of HP, which can be more expensive than the regular ones. We also noticed that the market for HP in Porto is small; besides, there is no good supply chain, and we could even deduce that the supply of products is not adequate. For all these reasons, we see that only one of the elements of the TPB applies and has importance in our case. Thus, the subjective norm prevails strongly and decisive for the purchasing intention of HP. However, all the other elements seem not to be relevant in our study. Therefore, the halāl market should consider the TPB model as its results provide a compelling insight into haläl purchase behavior.

\section{Managerial Implications}

In practice, managers can learn the needs and challenges of a specific market segment with 
characteristics such as the Muslim community in Porto instead of the consumption of HP. Furthermore, this research allows managers to understand what influences purchasing behavior, especially in religious communities such as the Muslim community, from a business perspective. In the case of Porto, managers should keep in mind that social pressure is the most crucial determinant for the PI of HP. Other elements can also influence, but those vary according to the environment and context. In addition, research can demonstrate the great importance of haläl certification for consumers.

Furthermore, the results of the survey tell us clearly that the supply of HP is not sufficient in the city of Porto, which could be a great business opportunity as we can infer that there is an unsatisfied demand, there is a need for better services and a better supply of halāl certified products. Therefore, researchers can apply this not only regarding HP or PI consumption but also another concept. Furthermore, since this study is a pioneer because there is no other existing studying in Portugal that has to explore the needs of a community, this can be a starting point for future research and a more complex subject. Finally, there seems to be unsatisfied demand that could be better analyzed, and the paper allows academics to understand the current situation of the market of HP in Porto.

\section{Limitations}

The study has several limitations. Firstly, data were collected only in the city of Porto, and the results may differ from data from another geographical area. In addition, the sample is too small to be generalized. Furthermore, problems were encountered when collecting information from the respondents. For example, not all of them had access to the internet, and not all of them spoke English or Portuguese correctly, which made data collection difficult. Another significant limitation is that the population of Muslims living in Porto is small.

Furthermore, from a theoretical perspective, the TPB model assumes that all people have identical belief structures, which is not necessarily correct. The Muslim community is composed of different believers with different backgrounds. Finally, another limitation was the time to carry out this research, being the time very limited otherwise, perhaps we could have reached a larger sample.

\section{Directions for Future Research}

Future comparative research between countries could be carried out to find points of agreement. The basic TPB model was used as a basis for the study, limiting the explanatory factors examined. Therefore, we could add variables such as Control structure, Behavioural intention, Normative structure, and the Facilitating conditions or even propose a more complex model where a direct relationship of all independent variables to a single dependent is tested. For example, we could study Subjective Norm plus Self-identity plus Control over perceived behavior influencing the attitude and then influencing PI. Furthermore, a future study could be focused on a particular group of Muslims or by nationality. We suggest an investigation of why outside a Muslim country, it is more difficult to follow its society's rules, religious principles, and characteristics. Finally, we suggested a depth analysis of the perception of other players in the hala $l$ market, such as the manufacturers or retailers themselves. 


\section{REFERENCES}

Abdul-Talib, A., \& Abd-Razak, I. (2013). Cultivating export market-oriented behavior in halāl marketing: Addressing the issues and challenges in going global. Journal of Islamic Marketing, 4(2), 187-197. doi: https://doi.org/10.1108/17590831311329304

Abu, A., Arshad, R., Abdullah, C., Bakar, A., \& Ramli, Z. (2018). Capturing the halāl food market: Limitations of halāl integrity within the supply chain, the Malaysian experience. American Journal of Economics, 8(6), 272-278.

doi: https://doi.org/10.5923/j.economics.20180806.06

Aditami, S. (2016). The analysis of HP PI using theory of planned behavior (Tpb): An application on Bakery product consumption (Bachelor thesis). Muhammadiyah University of Surakarta, Surakarta, Indonesia.

Ahmad, A. N., Rahman, A. A., \& Rahman, S. A. (2015). Assessing knowledge and religiosity on consumer behavior towards halāl food and cosmetic products. International Journal of Social Science and Humanity, 5(1), 10-14.

doi: https://doi.org/10.7763/ijssh.2015.v5.413

Ahmed, W., Najmi, A., Faizan, H. M., \& Ahmed, S. (2019). Consumer behaviour towards willingness to pay for HP: An assessment of demand for haläl certification in a Muslim country. British Food Journal, 121(2), 492-504.

doi: https://doi.org/10.1108/BFJ-02-2018-0085

Ajzen, I. (1985). From intentions to actions: A theory of planned behavior. In J. Kuhl \& J. Beckman (Eds.), Action-control: from cognition to behavior (pp. 11-39). Springer.

Ajzen, I. (1991). The theory of planned behavior. Organizational Behavior and Human Decision Processes, 50(2), 179-211. doi: https://doi.org/10.1016/0749-5978(91)90020-T

Ajzen, I. (2008). Consumer attitudes and behavior. In C. P. Haugtvedt, P. M. Herr, \& F. R. Cardes (Eds.), Handbook Consumer psychology (pp. 525-548). Lawrence Erlbaum Associates.

Ali, A., \& Sherwani, M. (2017). Shaping halāl into a brand? Factors affecting consumers' halāl brand PI. Journal of International Food and Agribusiness Marketing, 29(3), 234259. doi: https://doi.org/10.1080/08974438.2017.1312657

Ali, M., Ismail, A., Alam, S., Makhbul, Z., \& Omar, N. (2018). Exploring the theory of planned behaviour (TPB) in relation to a halāl food scandal: The Malaysia Cadbury chocolate case. International Food Research Journal, 25, S79-S86.

Awan, H. M., Siddiquei, A. N., \& Haider, Z. (2015). Factors affecting halāl PI-Evidence from Pakistan's halāl food sector. Management Research Review, 38(6), 640-660. doi: https://doi.org/10.1108/mrr-01-2014-0022

Bonne, K., \& Verbeke, W. (2008). Muslim consumer trust in halāl meat status and control in Belgium. Meat Science, 79(1), 113-123. doi: https://doi.org/10.1016/j.meatsci.2007.08.007

Bonne, K., Vermeir, I., Bergeaud-Blackler, F., \& Verbeke, W. (2007). Determinants of halāl meat consumption in France. British Food Journal, 109(5), 367-386.

doi: https://doi.org/10.1108/0070700710746786 
Delener, N. (1994). Religious contrasts in consumer decision behaviour patterns: their dimensions and marketing implications. European Journal of Marketing, 28(5), 36-53. doi: https://doi.org/10.1108/03090569410062023

Dutta, T., \& Mandal, M. (2018). Neuromarketing in India: Understanding the Indian consumer. In Neuromarketing in India: Understanding the Indian Consumer. Routledge. doi: https://doi.org/10.4324/9781351269360

European Commision. (2020). How the Islamic community in Portugal observes Ramadan during COVID-19. Retrieved from https://bit.ly/2W9ebKf

Farah, M. F. (2020). Consumer perception of halāl products: an empirical assessment among sunni versus shiite muslim consumers. Journal of Islamic Marketing, 12(2), 280-301. doi: https://doi.org/10.1108/jima-09-2019-0191

Grand View Research .(2018). Haläl food and beverage market size worth $\$ 739.59$ billion by 2025". Retrieved from https://bit.ly/3z4z5Iy

Giyahi, Y., \& Khashei Varnamkhasti, V. (2019). Iranian customers' understanding towards halāl logo and Islamic brands. Journal of Islamic Business and Management, 9(2), 442-458. doi: https://doi.org/10.26501/jibm/2019.0902-014

Kamalul, S., Dihanan, N., \& Wahid, N. (2019). Investigating the Factors Affecting consumer PI towards haläl organic food. Journal of Entrepreneurship, Business, and Economics, $7(2), 162-188$.

Kettani, H. (2010). Muslim population in Europe: 1950-2020. International Journal of Environmental Science and Development, 1(2), 154-164.

Malhotra, N., Baalbak, I., \& Bechwati, N. (2010). Marketing research. Pearson Prentice Hall.

Mullen, K., Williams, R., \& Hunt, K. (2000). Irish descent, religion, and food consumption in the west of Scotland. Appetite, 34(1), 47-54.

doi: https://doi.org/10.1006/appe.1999.0292

Noor, A., Farah, A., \& Aflah, I. (2014). Determinants of halāl PI: Case in Perlis. International Journal of Business and Social Research, 4(5), 118-123.

Park, J., \& Park, M. (2016). Qualitative versus quantitative research methods: Discovery or justification? Journal of Marketing Thought, 3(10), 1-7. doi: https://doi.org/10.15577/jmt.2016.03.01.1

Pettinger, C., Holdsworth, M., \& Gerber, M. (2004). Psycho-social influences on food choice in Southern France and Central England. Appetite, 42(3), 307-316. doi: https://doi.org/10.1016/j.appet.2004.01.004

Phan, T., \& Mai, P. (2016). Determinants impacting consumers' PI: The case of fast food in Vietnam. International Journal of Marketing Studies, 8(5), 56-68. doi: https://doi.org/10.5539/ijms.v8n5p56

Salman, F., \& Siddiqui, K. (2011). An exploratory study for measuring consumers awareness and perceptions towards haläl food in Pakistan. Interdisciplinary Journal of Contemporary Research in Business, 3(2), 639-651.

Saunders, M., Lewis, P., \& Thornhill, A. (2000). Research methods for business students. In Research Methods for Business Students (Vol. 3). doi: https://doi.org/10.1108/qmr.2000.3.4.215.2 
Shafique, S., Zia, M. H., Rajput, A., Shafi, K., \& Shareef, A. (2019). Muslim consumers style inventory: A case from Pakistan. Journal of Islamic Business and Management (JIBM), 9(2), 416-429. doi: https://doi.org/10.26501/jibm/2019.0902-012

Shah, S., \& Mohamed, N. (2011). Applying the Theory of Planned Behavior (TPB) in halāl food purchasing. International Journal of Commerce and Management, 21(1), 8-20. doi: https://doi.org/10.1108/10569211111111676

Shah, S. A., Azhar, S. M., \& Bhutto, N. A. (2019). Ḥalāl marketing: A marketing strategy perspective. Journal of Islamic Marketing, 11(6), 1641-1655.

Taylor, S., \& Todd, P. (1995). Decomposition and crossover effects in the theory of planned behavior: A study of consumer adoption intentions. International Journal of Research in Marketing, 12(2), 137-155. doi: https://doi.org/10.1016/0167-8116(94)00019-K

Venkatesh, V., \& Davis, F. (2000). Theoretical Extension of the Technology Acceptance Model: Four longitudinal field studies. Management Science, 46(2), 186-204. doi: https://doi.org/10.1287/mnsc.46.2.186.11926

Wee, C., Ariff, M., Zakuan, N., Tajudin, M., Ismail, K., \& Ishak, N. (2014). Consumers perception, PI, and actual purchase behavior of organic food products. Review of Integrative Business and Economics Research, 3(2), 378-397. 